\title{
IDŐJÁRÁS
}

Quarterly Journal of the Hungarian Meteorological Service

Vol. 123, No. 1, January-March, 2019, pp. 107-126

\section{Predicting future shift of drought tolerance zones of ornamental plants in Hungary}

\author{
Ákos Bede-Fazekas ${ }^{1,2, *}$ and Krisztina Szabó ${ }^{3}$ \\ ${ }^{1}$ MTA Centre for Ecological Research, \\ Institute of Ecology and Botany, \\ H-2163 Vácrátót, Alkomány u. 2-4., Hungary \\ ${ }^{2}$ MTA Centre for Ecological Research, \\ GINOP Sustainable Ecosystems Group, \\ H-8237 Tihany, Klebelsberg Kuno u. 3., Hungary \\ ${ }^{3}$ Szent István University, \\ Faculty of Landscape Architecture and Urbanism; \\ H-1118 Budapest, Villányi út 29-43., Hungary \\ *Corresponding author E-mail: bede-fazekas.akos@okologia.mta.hu
}

(Manuscript received in final form April 4, 2018)

\begin{abstract}
Climate of Hungary, Central Europe, is predicted to undergo substantial aridification by 2100 due to the decrease of precipitation in the summer season. Dendrology and ornamental plant application require adaptation to these climatic changes. This paper aims at giving guidance for landscape architects, dendrologist, and horticulturists by providing spatial predictions on both drought tolerance zones of ornamental plants and the amount of needed irrigation (i.e., precipitation deficit). Future climate of two prediction periods (2025-2050, 2071-2100) are compared to that of the reference period (1961-1990), based on regional climate model RegCM3 driven by IPCC SRES scenario A1B. Three drought tolerance zones are studied that are found to shift northward in the future. It is predicted that, by the end of the 21 st century, the less drought tolerant ornamental plants applied countrywide nowadays will lose the chance to survive without considerable irrigation efforts in Baranya, Bács-Kiskun, and Csongrád counties (southern Hungary). Since nursery production is now located in those regions that may be mostly affected by aridification, it needs planning adaptation measures.
\end{abstract}

Key-words: climate change, drought tolerance, dendrology, predictive ecological model 


\section{Introduction}

Hungary's ornamental plant production is noteworthy: the number of cultivated species and cultivars exceeds 4000 . The predicted future warming of the Hungarian climate and the increasing aridity will affect ornamental plant production (Schmidt, 2006) and plant application as well (Bede-Fazekas, 2017). Changing climate forces us not only to apply new species, cultivars, and even cultivation methods (e.g., plant protection against new pests and diseases, economical irrigation, etc.) but also to eliminate those species and genera from the list of recommended plants that prefer humid and wet environment (e.g., Chamaecyparis, Hydrangea, Hypericum, Magnolia; Szabó and Bede-Fazekas, 2012). The direct negative impacts of aridity on horticultural plants include the unfavorable shift in phenology (the time and length of flowering, fruiting, defoliation, etc.), in pollination, problems in nutrients intake, decrease of lifespan, or even the death of plants (Soltész et al., 2011; BedeFazekas et al., 2015, Bede-Fazekas, 2017). In Hungary, selection of stress tolerant ornamental plants has started in the 1950's with taxa Sorbus, Tilia, Fraxinus, Cornus, and Juniperus. The continuation of this research on cultivar selection, and especially that of the drought tolerant cultivars, may get even more importance during the struggle against aridity and seems to became essential in the future (Szabó and Bede-Fazekas, 2012). Besides using native species, the newly introduced alien taxa might also enrich the assortment.

Climatic perspectives are important from the point of view of landscape architecture, horticulture, and maintenance as well. The application of droughttolerant plant species can help decreasing the frequency and quantity of required irrigation. Thus, total cost of afforestation or planting may be reduced. Only $27 \%$ of the easily obtainable ornamental plant species of Hungary are droughttolerant ones (Szabó and Bede-Fazekas, 2012).

Hungary is located in the temperate zone, on the border of different climatic subzones. A Mediterranean-like climate is predominant in the south and southwestern parts, while the continental climate features are dominant in the eastern parts, and atlantic climate features influence the western counties. The southern and southeastern parts are rich in submediterranean species. Due to the geographic position of the Carpathian Basin, the mean temperature of Hungary is slightly higher than that of the areas on the same latitude. Topography of Hungary is relatively uniform: on a large scale, there is no significant difference in the climate of the regions (Bacsó, 1966).

The sum and distribution of precipitation is a limiting factor that may become more important for the future plant application than for nowadays. The dry areas of Hungary are situated in central territories of the Pannonian Plain, where average annual rainfall is under $500 \mathrm{~mm}$ and the number of summer days is outstanding (85) (Steinhauser, 1970; Pálfai, 2002). Approximately 90\% of the territory of Hungary is endangered with aridity, and only the western parts of Hungary are free from aridity (Vermes et al., 2000). The aridity problem will grow in the future, 
which one has to think about, and prepare for, in terms of plant application. These findings are in accordance with current aridity maps (Steinhauser, 1970; Pálfai, 2002) and predictions (Bartholy and Pongrácz, 2005; Sheffield and Wood, 2008; Lakatos et al., 2011; Bartholy et al., 2013; Pongrácz et al., 2014).

Future climate change is predicted to greatly affect Hungary. Although the increase of the annual and seasonal temperature is predicted by global and regional models in great agreement, the change in precipitation sum and monthly precipitation distribution is highly uncertain (Torma, 2011; Van Oldenborgh et al., 2013; Pongrácz et al., 2014). The country is located between the northern and southern parts of Europe, where annual precipitation sum is predicted to increase and decrease, respectively (Van Oldenborgh et al., 2013). According to the model ensemble of the FORESEE database (Dobor et al., 2015), precipitation sum of Central Europe might decrease by 3\% by the end of the 21 st century. The frequency of extreme drought events in Hungary is predicted to increase, mainly in summer and spring, according to an ensemble of 11 models (Pongrácz et al., 2014).

According to RegCM and Aladin regional climate models, annual mean temperature of Hungary may increase by $1-2{ }^{\circ} \mathrm{C}$ and $3-5^{\circ} \mathrm{C}$ by the periods 2021-2050 and 2071-2100, respectively (Sábitz et al., 2015). RegCM predicts moderate warming $\left(<1{ }^{\circ} \mathrm{C}\right)$ in summer and fall for the near future period, but, in agreement with Aladin model, increase of the temperature of these seasons is more pronounced by the end of the century (Torma, 2011; Sábitz et al., 2015). For annual precipitation, RegCM is much more pessimistic than Aladin for the period 2021-2050, while their order change if period 2071-2100 is studied (Sábitz et al., 2015). According to RegCM, while most part of the country, and most of all the southern parts, will suffer from precipitation decrease in the near future period, almost one third of Hungary will undergo increase of precipitation (Torma 2011; Sábitz et al., 2015).

Similarly to the findings of Bartholy et al (2008) on a model ensemble, RegCM predicts the decrease of monthly variability of the precipitation: summer, which is now the wettest season, will undergo an aridification, while the driest winter may get more precipitation in the future (Torma 2011; Sábitz et al., 2015). Expected temperature and precipitation changes are confirmed by the prediction of Belda et al. (2015).

Climate of Hungary in the period of 2011-2040 is predicted to be similar to the past (i.e., 1961-1990) climate of South Romania, North Bulgaria, North Greece, Serbia, and Macedonia. In the period of 2071-2100 it is expected to be analogous with the North Africa region (Horváth, 2008).

In this paper we aimed to locate drought-tolerance zones that relate to the three drought-tolerance categories specified in our previous study (Szabó and Bede-Fazekas, 2012) and to predict future shift of these zones. Moreover, we aimed to support maintenance planning with maps of predicted water deficit (needed amount of irrigation water). 


\section{Materials and methods}

\subsection{Definition of drought tolerance zones}

Drought tolerance categories were defined in a way that enables them to serve as proxies for the 3-class classification of the plant material of the most important Hungarian nurseries according to Szabó and Bede-Fazekas (2012). Aggregated species list of the category 'drought tolerant' of Szabó and Bede-Fazekas (2012) and the related categories '1-1', '1-2', '1-3', and '1-4' of climate-species matrix defined by Roloff et al. (2009) are available from the Supplementary Material S1. Suitability of the listed species for dry habitats were checked against finding in other sources (e.g., Krüssmann, 1977; Retkes and Tóth, 2004, 2015; Tóth 2012; Schmidt et al., 2013).

Calculation of the three drought tolerant zones is based on indicator functions, Eqs. (1-3), that result in 1 (true value) if the mean of maximum temperature of summer months and the precipitation sum of the vegetation period are larger/smaller than certain values. These values $\left(24.0^{\circ} \mathrm{C}, 25.5^{\circ} \mathrm{C}\right.$, and $290 \mathrm{~mm}, 330 \mathrm{~mm}$ ) were selected to fulfill our secondary aim, that was the separation of the territory of Hungary in a way, that results in three subterritories comparable to each other in terms of their area.

$$
\begin{gathered}
I_{1}^{p}=\left(\frac{\sum_{m \in[6,8]} \operatorname{Tmax}_{m}^{p}}{3}>25.5^{\circ} \mathrm{C}\right) \wedge\left(\sum_{m \in[4,9]} P_{m}^{p}<290 \mathrm{~mm}\right) \\
I_{2}^{p}=\left(\frac{\sum_{m \in[6,8]} \operatorname{Tmax}_{m}^{p}}{3}>24.0^{\circ} \mathrm{C}\right) \wedge\left(\sum_{m \in[4,9]} P_{m}^{p}<330 \mathrm{~mm}\right) \wedge \neg I_{1}^{p} \\
I_{3}^{p}=\neg I_{1}^{p} \wedge \neg I_{2}^{p}
\end{gathered}
$$

In Eqs. (1-3), $I_{\mathrm{n}}^{p}$ is the indicator function of drought tolerant zone $n(n \in[1,3])$ in the period $p(p \in[1961-1990,2021-2050,2071-2100]) . \operatorname{Tmax}_{m}^{p}$ and $P_{m}^{p}$ mean are the maximum temperature and precipitation, respectively, of month $m$ averaged in the period $p$.

\subsection{Data and software}

Climatic data from the reference period (1961-1990) and the prediction periods (2025-2050, 2071-2100) were derived from the downscaled RegCM3 regional climate model (Torma et al., 2008, 2011), one of the high-resolution RCMs of the project Central and Eastern Europe Climate Change Impact and Vulnerability Assessment (CECILIA). RegCM is based on the IPCC SRES scenario A1B (Nakićenović and Swart, 2000). Daily maximum ground temperature and daily precipitation were obtained from the grid with horizontal 
resolution of $10 \mathrm{~km}$, and monthly means of maximum temperature and sums of precipitation were calculated and then averaged in the three studied periods. Instead of observed climatic data, modeled data were used in case of the reference period, and no bias correction of the modeled future data were done, since the aim of this study was a comparison of drought tolerance zones and the detection of future change, rather than analysis of future climate. Hence, our results are not comparable to those of studies based on observed climatic data and bias corrected model results.

Modeling and displaying of the results were done by ESRI ArcGIS 10.0 geoinformation software, and statistics were calculated by $\mathrm{R}$ statistical environment (R Core Team, 2014). Data Management and Spatial Analyst extensions of ArcGIS, and packages sp (Pebesma and Bivand, 2005; Bivand et al., 2013), rgdal (Bivand et al., 2014), raster (Hijmans, 2015), and maptools (Bivand and Lewin-Koh, 2015) of R were used.

\subsection{Modeling the shift and precipitation deficit of drought tolerance zones}

Modeling the shift of drought tolerance zones was started by calculating the mean of summer maximum temperature and sum of precipitation of the vegetation period in case of all the grid points and the three studied periods. It was done by creating two new columns of float number format and calculating the values using a Python script. The new values were interpolated with inverse distance weighted (IDW) method, using cell size 0.01 decimal degrees (of WGS-84 geographic system), $2^{\text {nd }}$ power and 12 neighbor variables. The drought tolerance zones were identified by the Raster Calculator tool.

Modeling the precipitation deficit of drought tolerance zones was based on the previously calculated and interpolated precipitation sum of the vegetation period. The values were displayed with manually set categorization according to the difference between the limiting value of the drought tolerance category and the modeled values. Temperature and precipitation limits were displayed based on the Contour tool of the Spatial Analyst extension.

\subsection{Statistics on precipitation and the ratio of zones}

Calculation of statistics was started by setting up the geoinformation environment in $\mathrm{R}$ (loading packages, opening data, transforming data in order to their projection math each other). Then masking of the raster of the drought tolerance zones and the precipitation sum of the vegetation period by the polygons of counties was done. Minimum, maximum, mean, and standard deviation of precipitation, and area ratio of the three drought tolerance zones within the counties were calculated in iterative way. Results were exported to shape files in order to display them in ArcGIS. 


\section{Results}

\subsection{Shift of drought tolerance zones}

Drought tolerance zones are predicted to shift northward during the 21 st century in accordance with the global and regional climate predictions. The extension and situation of the zones (Fig. 1) are found to change much more by the far future (2071-2100) period than by the near future (2021-2050). Zone 1 is found in the southern part of Hungary in the reference period, and is predicted to become fragmented but not undergo expansion by the near future period. By the end of the century, it is predicted to double its area by incorporating almost the entire territory of Somogy, Baranya, Tolna, Bács-Kiskun, and Csongrád counties, embracing the lake Balaton and reaching Budapest from south. The most noteworthy northward expansion of zone 1 is predicted to occur in the western part of the country (Dunántúl) by reaching Szombathely (Vas County) in the far future period.

Drought tolerance zone 2 is delimited from the zone of least tolerant ornamental plants (i.e., zone 3) by the lake Balaton, Budapest, and Hortobágy (Hajdú-Bihar County) in the reference period. An isolated part is found in the northwestern corner of the country, which is predicted to become wetter in 2021-2050 (i.e., will belong to zone 3). In the near future period, while remarkably northward shift of zone 2 can be observed in Vas and Zala counties (western Dunántúl), its seems to stand in its place in the eastern parts. In the far future period, zone 2 may reach the north border of Hungary. Some territories, e.g., Mecsek Mountains (Baranya and Tolna counties) and the touch of Fejér and Bács-Kiskun counties (south to Budapest), are predicted to consistently belong to zone 2 from 1961 to 2100 .

Zone 3, the zone of the least drought tolerant species, covers the northern parts of the country in the reference period, and gradually moves back to the northeastern region by abandoning Zala, Vas, and the half of Györ-MosonSopron counties in the future periods. Zone 3 is not predicted to change substantially in the eastern region (Tiszántúl). While in the reference period, the zone includes most parts of Hungary of high altitudes, Dunántúli Mountains seems to suffer a considerable aridification: zone 2 will reach it in the near future, and zone 1 in the far future period. Northern Mountains are predicted to be much less affected. 

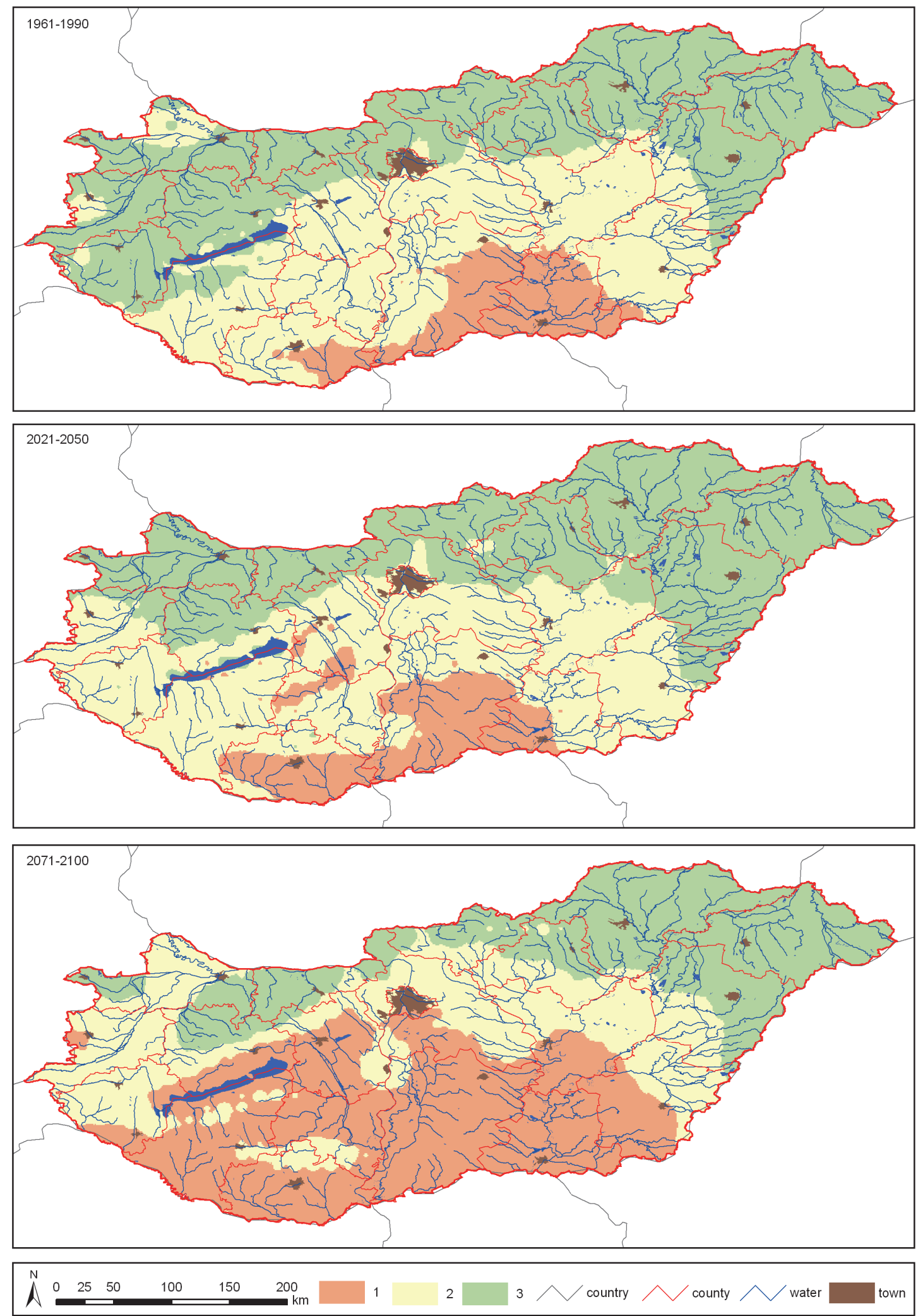

Fig. 1. Drought categories 1, 2, and 3 (see detailed in Section 2) in the reference period (1961-1990, top) and the two prediction periods (2021-2050, center; 2071-2100, bottom). 


\subsection{Precipitation deficit of drought tolerance zones}

Results on precipitation deficit foreshadow that in case of the zone of the less drought tolerant ornamental plants, i.e., zone 2 and zone 3, the needed irrigation water quantity will gradually grow by the end of the 21 st century. Although the precipitation deficit shows southward increase throughout the country, this zonality is most easily observed in the eastern part of Hungary.

By studying precipitation deficit relative to zone 3 (Fig. 2), one can estimate the impact of future climate change on the irrigation needs of the least drought tolerant ornamental species. While in the reference period, precipitation deficit is under $50 \mathrm{~mm}$ almost everywhere in the country, southern regions and the surroundings of the lake Balaton are predicted to suffer greater deficiency both in the near and the far future prediction periods. The most precipitation deficient areas, i.e., where more than $70 \mathrm{~mm}$ irrigation will be needed, occur in limited parts of Bács-Kiskun and Baranya counties in 2021-2050, while they are predicted to expand substantially by the period 2071-2100 and contain half of Csongrád County. Precipitation deficit in the near future period may reach $60 \mathrm{~mm}$ in the region which belongs to zone 3 in the reference period. This sudden change will affect the western part of Hungary, most of all the surroundings of the lake Balaton. In most of the other deficient regions, substantial change between the reference and near future periods is not predicted. Areas of the contraction of zone 3 between the two future periods, i.e. mostly northwestern Hungary, will suffer much less deficit $(0-20 \mathrm{~mm})$ in 2071-2100. Not considering the border of zone 3, the least aridification is predicted to occur in Mecsek Mountains (Baranya and Tolna counties). Results imply that despite the slow and minor changes by 2021-2050 in great part of the country, Baranya and Veszprém counties will undergo a substantial and rapid aridification. Change in Baranya County is contradictory: the smallest and largest deficit occur within $50 \mathrm{~km}$ distance from each other. By the end of the century, the aridification may become more expanded and more considerable in most of those parts of Hungary that does not belong to zone 3 .

While precipitation deficit relative to zone 2 (Fig. 3) is less than $20 \mathrm{~mm}$ everywhere in the reference period, it can exceed $30 \mathrm{~mm}$ in one southern county (Baranya) in the near future prediction period, and two more counties (BácsKiskun and Csongrád) in the far future period. Surroundings of the lake Balaton is predicted to suffer even more than $30 \mathrm{~mm}$ deficit in 2071-2100. 0-20 mm deficit is predicted in the period 2021-2050 for those regions that are abandoned by zone 2 (Fejér, Tolna, Baranya, and Bács-Kiskun counties). Those areas that belong to zone 2 in the near future period but are classified as zone 1 in the far future period, will suffer greater aridification up to $30 \mathrm{~mm}$ precipitation deficit, or more. 
Figs. 2 and 3 show temperature and precipitation limits of the zones separately. The results indicate that both of zone 3 and zone 2 are limited mainly by precipitation in their southern (i.e., arid) border. Those isotherms that limits zone 3 and zone 2 by definition $\left(24\right.$ and $25.5^{\circ} \mathrm{C}$, respectively) run near the related isohyets (330 and $290 \mathrm{~mm}$, respectively) in the reference period. In the near future period, the isotherms detach more from the isohyets and have minimal impact on the location of the zones. In the far future period, the isotherms run mainly north to the northern border of Hungary, and does not affect the expansion of the zones.

\subsection{Statistics on precipitation and the ratio of zones}

County-level descriptive statistics on the precipitation of the vegetation period (Table 1 - mean and standard deviation, Table 2 - minimum and maximum) confirm our previous findings. Although almost all the countries (except SSB) will suffer more or less aridification by the end of the 21st century, the tendency is not monotonic in case of Bar, BAZ, Bek, GMS, HB, Hev, JNS, KE, Nog, Pes, and $S S B$. Gradual aridification is predicted to occur mainly in the counties of Dunántúl (western Hungary). The mean of the precipitation sum of the vegetation period is between 282.51-371.09 $\mathrm{mm}, 284.43-412.99 \mathrm{~mm}$, and $257.89-378.24 \mathrm{~mm}$ in the periods 1961-1990, 2021-2050, and 2071-2100, respectively. Since the statistical range of the mean precipitation is predicted to be larger in the future periods than in the reference period, climate of Hungary may be tolerable by more ornamental species. The overall tendency shows, however, aridification in most parts of the country. Driest counties are $C s o, B K$, and Bar. SSB is found to be consequently the wettest county in all the three studied periods (with no observable aridification), while $B a z, K E$, and Nog are also among the wettest counties.

Standard deviations vary between $4.64-33.67 \mathrm{~mm}, 6.4-49.92 \mathrm{~mm}$, and $6.41-37.82 \mathrm{~mm}$ in the periods 1961-1990, 2021-2050, and 2071-2100, respectively. Substantial standard deviations are found in Bar, BAZ, GMS, Pes, $S S B$ and Ves. The latter shows outstanding deviations in all the three periods (maximum is reached in the near future prediction period), which indicates that great spatial variations might occur within the county.

The smallest difference of the minimum and maximum values of precipitation sum of the vegetation period was found in $\mathrm{Tol}$ in the reference period, and it is predicted to occur in Bud in the two prediction periods. In accordance with the findings on the standard deviation, the greatest differences are presented in Ves not only in the reference but also in the two prediction periods. 

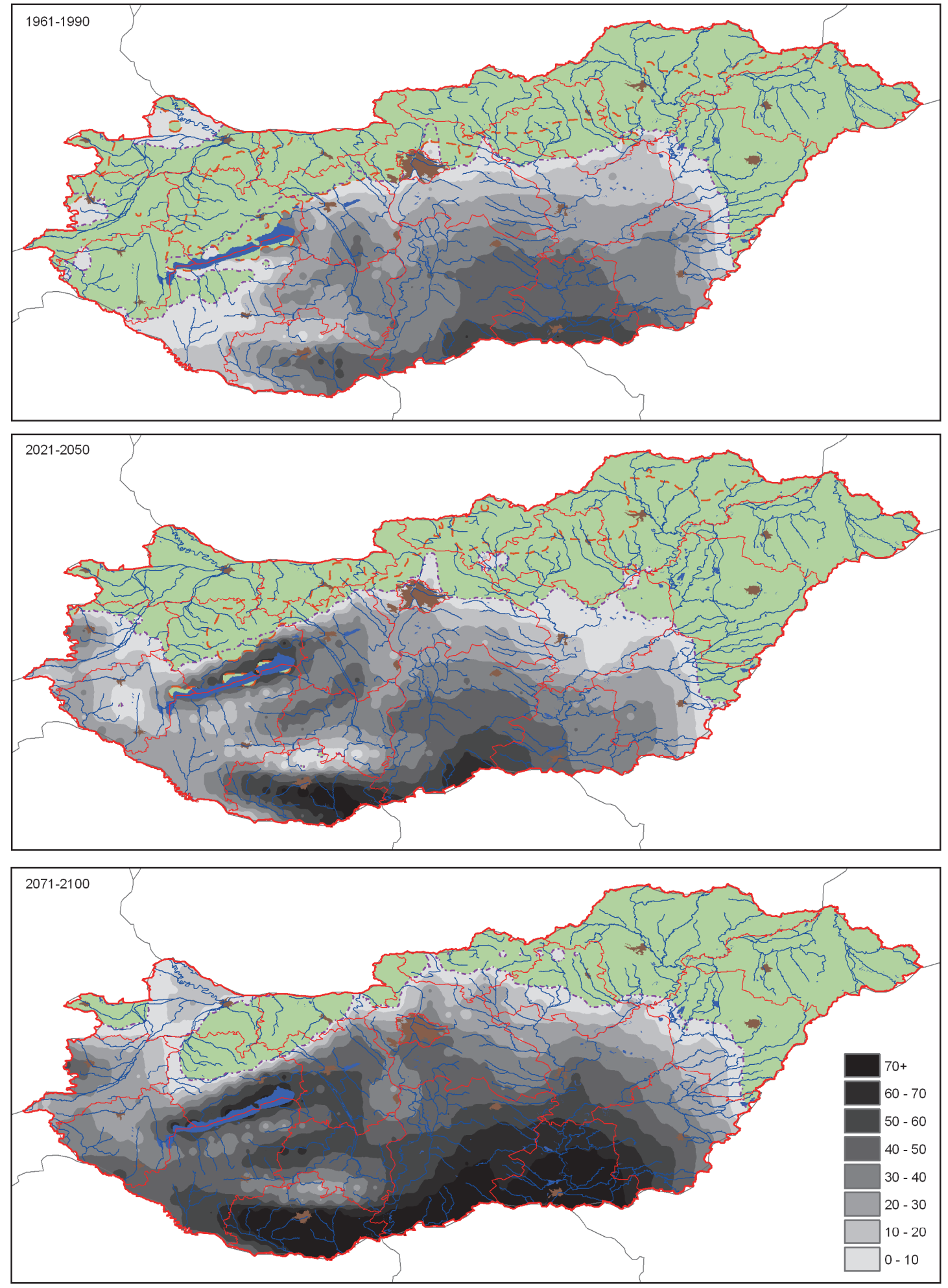

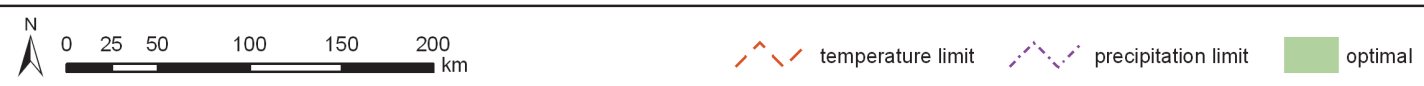

Fig. 2. Deficit of precipitation sum during the vegetation period $(\mathrm{mm}$; see greyscale legend on the bottom right corner) in the suboptimal territories of drought category 3 (see detailed in Section 2) in the reference period (1961-1990, top) and the two prediction periods (20212050, center; 2071-2100, bottom). Temperature (orange dashed line) and precipitation (purple dashed-dot line) limits of the drought category are also drawn. 

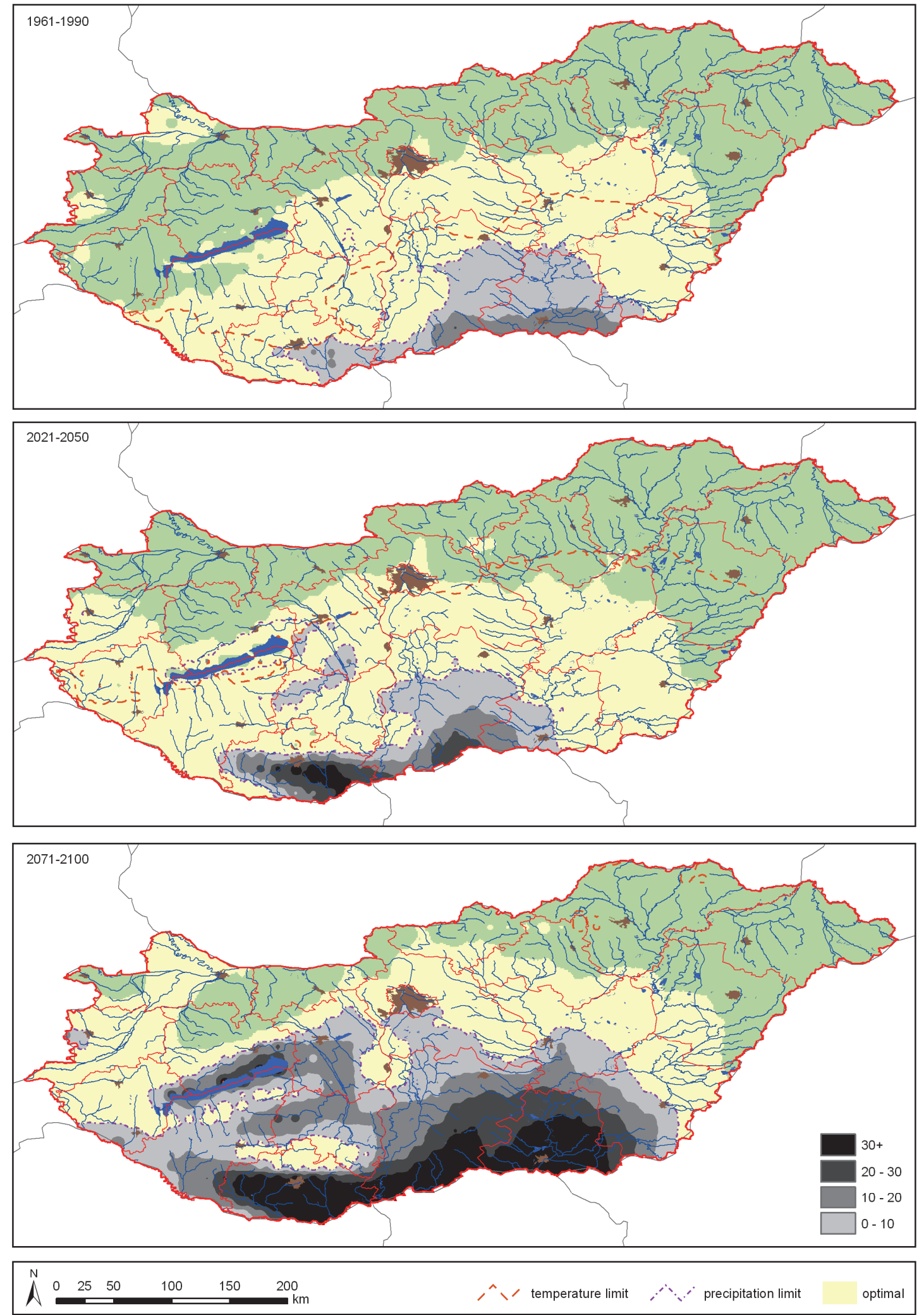

Fig. 3. Deficit of precipitation sum during the vegetation period (mm; see greyscale legend on the bottom right corner) in the suboptimal territories of drought category 2 (see detailed in Section 2) in the reference period (1961-1990, top) and the two prediction periods (20212050, center; 2071-2100, bottom). Temperature (orange dashed line) and precipitation (purple dashed-dot line) limits of the drought category are also drawn. 
Table 1. Mean and standard deviation (in the form of 'mean $\pm \mathrm{sd}$ ') of precipitation sum during the vegetation period $(\mathrm{mm})$ found within the 19 counties and the capital (Budapest) of Hungary in the reference period (1961-1990) and the two prediction periods (2021-2050, 2071-2100)

\begin{tabular}{|c|c|c|c|c|}
\hline ID & County name & 1961-1990 & 2021-2050 & 2071-2100 \\
\hline Bar & Baranya & $299.71 \pm 12.15$ & $284.43 \pm 21.04$ & $263.01 \pm 19.32$ \\
\hline$B A Z$ & Borsod-Abaúj-Zemplén & $368.19 \pm 21.3$ & $396.57 \pm 25.69$ & $367.78 \pm 18.33$ \\
\hline Bek & Békés & $302.84 \pm 12.38$ & $315.89 \pm 16.21$ & $290.23 \pm 16.02$ \\
\hline$B K$ & Bács-Kiskun & $291.27 \pm 6.8$ & $288.04 \pm 10.05$ & $269.76 \pm 12.56$ \\
\hline Bud & Budapest (capital) & $327.61 \pm 7.27$ & $317.72 \pm 6.4$ & $292.3 \pm 6.41$ \\
\hline Cso & Csongrád & $282.51 \pm 5.29$ & $290.46 \pm 7.08$ & $257.89 \pm 6.43$ \\
\hline Fej & Fejér & $315.83 \pm 19.49$ & $305.73 \pm 21.33$ & $290 \pm 15.67$ \\
\hline GMS & Győr-Moson-Sopron & $340.46 \pm 18.81$ & $363.51 \pm 22.85$ & $333.22 \pm 19.71$ \\
\hline$H B$ & Hajdú-Bihar & $341.85 \pm 15.54$ & $365.25 \pm 17.53$ & $336.37 \pm 13.77$ \\
\hline $\mathrm{Hev}$ & Heves & $348.33 \pm 16.36$ & $349.68 \pm 15.88$ & $327.9 \pm 14.24$ \\
\hline$J N S$ & Jász-Nagykun-Szolnok & $311.88 \pm 10.14$ & $325.2 \pm 9.01$ & $296.49 \pm 13.43$ \\
\hline$K E$ & Komárom-Esztergom & $369.84 \pm 10.67$ & $384.86 \pm 16.58$ & $345.31 \pm 16.42$ \\
\hline Nog & Nográd & $363.55 \pm 11.6$ & $364.08 \pm 14.61$ & $332.35 \pm 10.8$ \\
\hline Pes & Pest & $325.65 \pm 23.1$ & $326.13 \pm 22.94$ & $301.19 \pm 16.26$ \\
\hline Som & Somogy & $321.17 \pm 11.06$ & $301.37 \pm 10.45$ & $282.23 \pm 7.57$ \\
\hline$S S B$ & Szabolcs-Szatmár-Bereg & $371.09 \pm 23.73$ & $412.99 \pm 19.44$ & $378.24 \pm 20.71$ \\
\hline Tol & Tolna & $300.26 \pm 4.64$ & $299.07 \pm 9.39$ & $282.68 \pm 7.65$ \\
\hline Vas & Vas & $335.79 \pm 5.84$ & $320.11 \pm 12.99$ & $304.97 \pm 8.81$ \\
\hline Ves & Veszprém & $349.89 \pm 33.67$ & $335.68 \pm 49.92$ & $314.84 \pm 37.82$ \\
\hline Zal & Zala & $340.15 \pm 8.55$ & $311.05 \pm 9.36$ & $294.25 \pm 8.35$ \\
\hline
\end{tabular}


Table 2. Minimum and maximum (in the form of 'min-max') of precipitation sum during the vegetation period $(\mathrm{mm})$ found within the 19 counties and the capital (Budapest) of Hungary in the reference period (1961-1990) and the two prediction periods (2021-2050, 2071-2100)

\begin{tabular}{|c|c|c|c|c|}
\hline ID & County name & 1961-1990 & 2021-2050 & 2071-2100 \\
\hline Bar & Baranya & $277.63-328.34$ & $247.75-335.38$ & $230.31-314.41$ \\
\hline$B A Z$ & Borsod-Abaúj-Zemplén & $293.69-446.04$ & $305.65-459.64$ & $301.67-425.08$ \\
\hline Bek & Békés & $283.13-368.56$ & $291.88-380.37$ & $255.65-352.94$ \\
\hline$B K$ & Bács-Kiskun & $269.55-309.78$ & $263.86-317.34$ & $241.28-297.43$ \\
\hline Bud & Budapest (capital) & $314.75-352.63$ & $309.06-342.61$ & $281.07-313.35$ \\
\hline Cso & Csongrád & $269.11-294.61$ & $270.89-305.74$ & $243.53-273.69$ \\
\hline $\mathrm{Fej}$ & Fejér & $284.18-379.44$ & $276.54-398.86$ & $269.57-366.6$ \\
\hline GMS & Győr-Moson-Sopron & $319.24-419.58$ & $336.91-462.77$ & $308.18-416.53$ \\
\hline$H B$ & Hajdú-Bihar & $307.76-383.04$ & $326.53-401.62$ & $306.68-369.99$ \\
\hline $\mathrm{Hev}$ & Heves & $293.74-389.09$ & $305.72-417.84$ & $300.91-387.37$ \\
\hline$J N S$ & Jász-Nagykun-Szolnok & $285.49-343.97$ & $294.75-352.2$ & $266.05-325.65$ \\
\hline$K E$ & Komárom-Esztergom & $338.83-403.21$ & $343.12-436.78$ & 309.06-395.09 \\
\hline Nog & Nográd & $331.27-403.07$ & $317.6-405.36$ & 299.94-360.61 \\
\hline Pes & Pest & $293.13-418.32$ & $298.12-420.3$ & $281.68-373.81$ \\
\hline Som & Somogy & $258.83-346.28$ & $248.83-323.73$ & $248.61-304.98$ \\
\hline$S S B$ & Szabolcs-Szatmár-Bereg & $339.74-469.33$ & $375.25-494.64$ & $345.51-456.38$ \\
\hline Tol & Tolna & $287.2-319.16$ & $282.8-331.86$ & $261.66-311.25$ \\
\hline Vas & Vas & $319.19-357.27$ & $281.34-350.43$ & $270.56-328.59$ \\
\hline Ves & Veszprém & $268.18-426.12$ & $247.08-458.55$ & $247.3-403.91$ \\
\hline Zal & Zala & $293.51-363.85$ & $259.89-333.71$ & $253.04-315.37$ \\
\hline
\end{tabular}

County-level distribution of the three drought tolerance categories (Table 3, Fig. 4) shows inconsistencies. While in the reference period, homogeneously wet (i.e., entirely belonging to zone 3) counties are $K E, N o g$, and $S S B$, some other counties $(G M S, B A Z$, and $H B)$ join this group in the near future period, which indicates the opposite tendency of aridification. However, in the far future period, only $S S B$ remain homogeneously wet. Southeastern counties, such as Cso, JNS, $H B$, and Bek are also predicted to become wetter by 2021-2050. Some counties of Dunántúl (Fej, Ves, Vas, Zal, Som, Tol, and Bar) and BK show clear aridification by 2021-2050, as well. This contradiction confirms our findings on the countrywide range of mean precipitation sum. However, aridity is gradually increasing in terms of the number of the counties not containing area of drought category 1: 15, 13, and 7, in the periods 1961-1990, 2021-2050, and 2071-2100, respectively. 
The far future period is consistently drier than the near future period. Cso is found to be homogeneously dry (i.e., entirely belonging to zone 1), but other counties show the same tendency of aridification. Some counties (e.g., Vas and $\mathrm{Zal}$ ) that are dominated by category 3 in the reference period are predicted to become significantly drier by the end of the century, since they will not accommodate drought category 3 anymore.

Table 3. Spatial ratio of the drought categories 1, 2, and 3 (in the form of ' $1-2-3 \%$ '; see detailed in the Section 2) within the 19 counties and the capital (Budapest) of Hungary in the reference period (1961-1990) and the two prediction periods (2021-2050, 2071-2100)

\begin{tabular}{|c|c|c|c|c|}
\hline ID & County name & 1961-1990 & 2021-2050 & 2071-2100 \\
\hline Bar & Baranya & $27.05-72.95-0 \%$ & $\begin{array}{l}65.72-33.75- \\
0.52 \%\end{array}$ & $84.51-15.49-0 \%$ \\
\hline$B A Z$ & Borsod-Abaúj-Zemplén & $0-2.01-97.99 \%$ & $0-0.4-99.6 \%$ & $0-2.24-97.76 \%$ \\
\hline Bek & Békés & $5.81-89.88-4.3 \%$ & $0-82.41-17.59 \%$ & $\begin{array}{l}51.83-46.66- \\
1.51 \%\end{array}$ \\
\hline$B K$ & Bács-Kiskun & $42.36-57.64-0 \%$ & $58.22-41.78-0 \%$ & $96.1-3.9-0 \%$ \\
\hline Bud & Budapest (capital) & $0-70.49-29.51 \%$ & $0-95.22-4.78 \%$ & $40.83-59.17-0 \%$ \\
\hline Cso & Csongrád & $95.36-4.64-0 \%$ & $36.13-63.87-0 \%$ & $100-0-0 \%$ \\
\hline$F e j$ & Fejér & $0-75.46-24.54 \%$ & $\begin{array}{l}13.52-74.03- \\
12.45 \%\end{array}$ & $64.3-31.43-4.27 \%$ \\
\hline GMS & Győr-Moson-Sopron & 0-26.92-73.08\% & $0-0-100 \%$ & $0-60.44-39.56 \%$ \\
\hline$H B$ & Hajdú-Bihar & $0-26.1-73.9 \%$ & $0-0.36-99.64 \%$ & $0-35.97-64.03 \%$ \\
\hline $\mathrm{Hev}$ & Heves & $0-12.75-87.25 \%$ & $0-5.13-94.87 \%$ & $0-53.48-46.52 \%$ \\
\hline$J N S$ & Jász-Nagykun-Szolnok & $2.29-90.9-6.81 \%$ & $0-71.53-28.47 \%$ & $34.71-65.29-0 \%$ \\
\hline$K E$ & Komárom-Esztergom & $0-0-100 \%$ & $0-0-100 \%$ & $0-14.03-85.97 \%$ \\
\hline Nog & Nográd & $0-0-100 \%$ & $0-1.8-98.2 \%$ & $0-33.99-66.01 \%$ \\
\hline Pes & Pest & $0-65.11-34.89 \%$ & $0-66.43-33.57 \%$ & $\begin{array}{l}24.79-67.49- \\
7.73 \%\end{array}$ \\
\hline Som & Somogy & $0-76.52-23.48 \%$ & $2.02-95.23-2.75 \%$ & $86.09-13.91-0 \%$ \\
\hline$S S B$ & Szabolcs-Szatmár-Bereg & $0-0-100 \%$ & $0-0-100 \%$ & $0-0-100 \%$ \\
\hline Tol & Tolna & $0.46-99.54-0 \%$ & $16.5-83.43-0.07 \%$ & $84.1-15.9-0 \%$ \\
\hline Vas & Vas & $0-12.9-87.1 \%$ & $0-73.52-26.48 \%$ & $5.78-94.22-0 \%$ \\
\hline Ves & Veszprém & $0-8.04-91.96 \%$ & $\begin{array}{l}0.94-35.04- \\
64.02 \%\end{array}$ & $\begin{array}{l}34.32-31.58- \\
34.1 \%\end{array}$ \\
\hline Zal & Zala & $0-7.13-92.87 \%$ & $0-97.28-2.72 \%$ & $25.22-74.78-0 \%$ \\
\hline
\end{tabular}



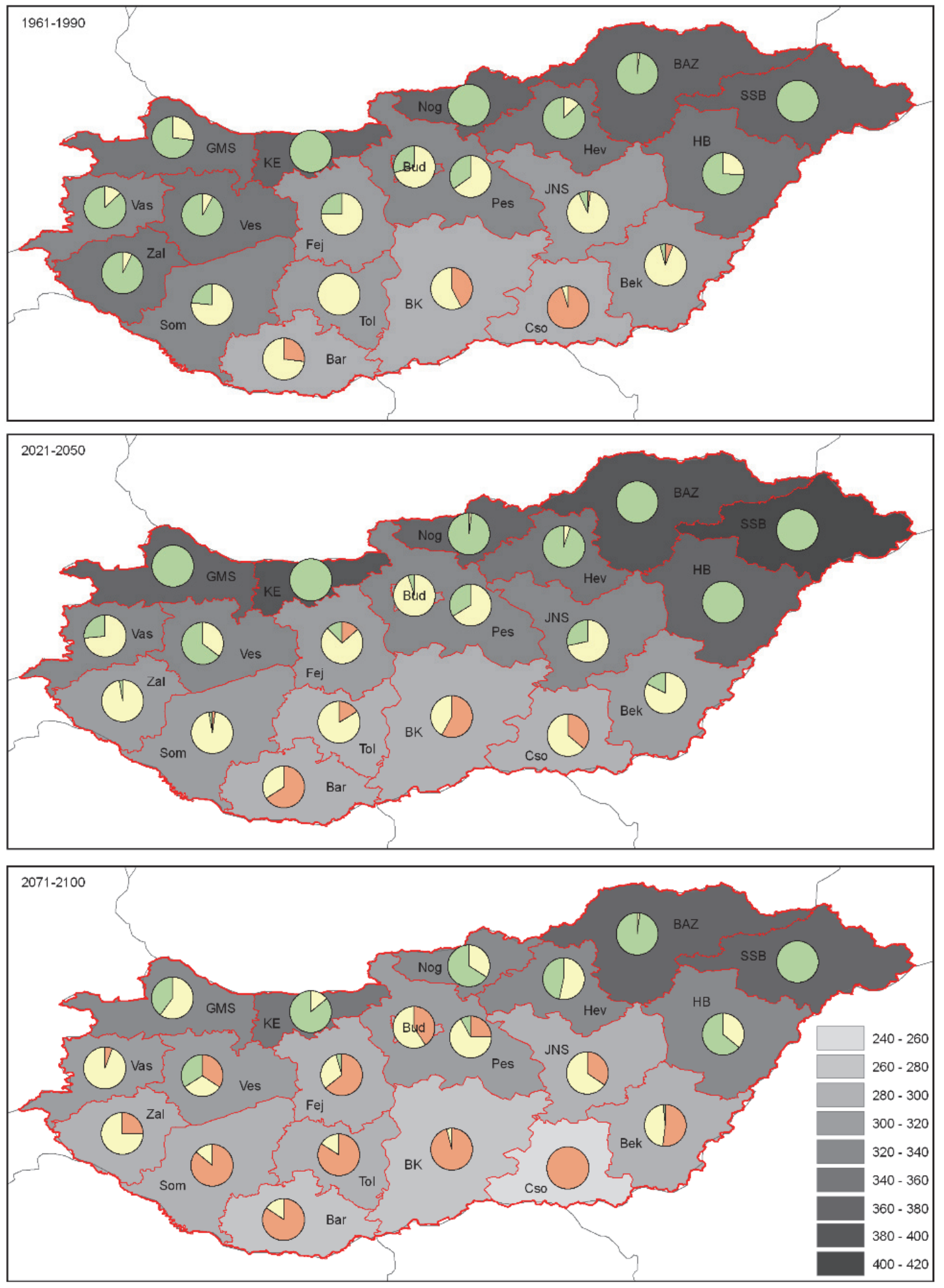

\begin{tabular}{|l|llllll|l|l|l|}
\hline $\mathrm{N}$ & $\mathbf{N}$ & 25 & 50 & 100 & 150 & 200 & & 1 & 2
\end{tabular}

Fig. 4. Spatial ratio of the drought categories 1, 2, and 3 (red, yellow, and green, respectively; see detailed in Section 2) and the mean of precipitation sum during the vegetation period (mm; see greyscale legend on the bottom right corner) found within the 19 counties and the capital (Budapest) of Hungary in the reference period (1961-1990, top) and the two prediction periods (2021-2050, center; 2071-2100, bottom) 


\section{Discussion}

During the 21st century, the drought hazard in Hungary is likely to increase in a spatially heterogeneous manner due to climate change. Comparing our prediction with another assessments showed little difference. Future changes based on De Martonne index, PAI index, and SAI index show that the highest drought level is located in the Pannonian Plain, and it decreases toward the north and west (Blanka et al., 2013). According to the drought map of the current state (Pálfai, 2004), the highest values (extremely high rate of exposure) are found in the central and southern part of the Pannonian Plain, and the lowest values are in the higher elevations of Alpokalja region (Vas County) and on the higher hills of Northern Mountains. According to our results, the higher hills of Northern Mountains, the northeastern part of the country, plain of Upper Tisza, and northern parts of Nyírség, Hajdúság, Marcal Basin, Komárom Plain, and Dunántúli Mountains remain relatively wet. The drought hazardous areas stretch out from the Pannonian Plain toward the western landscape units as far as the longitude of the lake Balaton. The aridity can cause problem, and needs adaptation, almost everywhere in Hungary in the 2071-2100 period. Budapest, the capital of Hungary, where plant application is limited by urban heat island, air pollution, and other disadvantages of being a metropolis, is predicted to be reached by the boundary of drought tolerance zone 1 in the far future period, that might make plant application more difficult.

More substantial changes are predicted to occur in the western region, while aridity of Tiszántúl seems to be relatively constant. Zonal distribution (Fig. 1) of the near future period is more similar to that of the reference period than to that of the far future period, even though the former is closer to it in term of time. This result implies that the progression of aridification will accelerate during the 21 st century. In the far future period, zone 2 is predicted shrink and provide a narrower buffer from zone 1 and zone 3, which indicates less balanced zonality and, therefore, less resistance to extreme drought events. Our predictions can not reject the hypothesis on climate extrapolation, i.e., the future strengthening of the continental effects on the east and the increase of dominance of Mediterranean effects of the south, which effects define now the climate of Hungary together with the Atlantic effects. Our results prove that the future climate of western part of Hungary may be more Mediterranean-like than it was in the reference period.

The results on the limiting isotherms and isohyets imply that more substantial warming (i.e., increase of maximum temperature) than decrease of precipitation of the vegetation period will occur in Hungary. Hence, future climatic conditions are predicted to have no precedent in the reference climate (1961-1990) of Hungary, which might complicate the adaptation.

Nursery production, that is now located partly in the Pannonian Plain and in western Hungary, may need to plan adaptation measures. Nowadays Vas and 
Zala counties are considered to be the wettest territories of Hungary providing excellent areas for developing of ornamental trees, shrubs, and specially, evergreens. According to our results, in the second prediction period, both these counties and those of the Pannonian Plain will suffer significant aridification that may hinder cost-effective nursery production. Production of some cultures (e.g., rose, bulb) will be possible under controlled and irrigated circumstances in the future (Soltész et al., 2011). Our research emphasizes the need of research on drought tolerance and drought tolerant plant selection, which has little literature in Hungary yet (e.g., Schmidt and Sütöriné Diószegi; 2010, Szabó and Gerzson, 2011; Maráczi and Baracsi, 2012).

The results are in line with the findings on the impact of future climate change on forests (Mátyás, 1994; Szentkirályi et al., 1998; Mátyás and Czimber, 2000) and on other seminatural vegetation types (Bede-Fazekas, 2017; Somodi et al., 2017; Bede-Fazekas et at., 2017). Our results emphasize that we have to pay more attention on ecological aspects and sustainability in the future. The desire for informed sustainable, ecological, and regenerative design is increasing everywhere, and is enhanced by the urgent need for adaptation to the warmer and more arid climate (Hunter, 2011; Beck, 2013; Bede-Fazekas, 2017). Substantial aridity, which we predicted in the far future period, threatens the structure and function of ecological communities in urban areas including public and private gardens (Hunter, 2011).

Since climate predictions show great uncertainty if precipitation change is studied in Central Europe (Torma, 2011; Van Oldenborgh et al., 2013; Pongrácz et al., 2014), selection of one regional climate model seems to be accidental. Therefore, our results seek for confirmation by model ensemble. This need is emphasized also by the fact that the selected model, RegCM, shows considerable differences to other regional climate models of the Carpathian Basin in terms of the relative similarity of the near future climate to the reference period (Sábitz et al., 2015; Bede-Fazekas, 2017). Our predictions are able to serve as quick overview of the possible impacts of future climate change on ornamental plant application, but can not substitute for ecological niche models. Therefore, instead of being interpretable in species or location level, our predictions provide guidance for landscape architects, dendrologists, and horticulturists to plan adaptation measures by making the spatial and temporal aspects of aridification tendencies available for studying them.

Supplementary Material: Supplementary Material S1. Aggregated species list of the category 'drought tolerant' of Szabó and Bede-Fazekas (2012) and the related categories '1-1', '1-2', '1-3', and '1-4' of climate-species matrix of Roloff et al. (2009). Species that are not mentioned by Roloff et al. (2009) are marked with asterisk.

Acknowledgements: The authors would like to express their gratitude to Csaba Torma for the data he has provided. The research was supported by the project TÁMOP-4.2.1/B-09/1/KMR-2010-0005 and the GINOP-2.3.2-15-2016-00019 grant. 


\section{References}

Bacsó, N., 1966: Bevezetés az agrometeorológiába. Mezőgazdasági Könyv- és Folyóiratkiadó Vállalat, Budapest, Hungary.

Bartholy, J., Pongrácz, R., Gelybó, Gy., and Szabó, P., 2008: Analysis of expected climate change in the Carpathian Basin using the PRUDENCE results. Idöjárás 112, 249-264.

Bartholy, J. and Pongrácz, R., 2005: Tendencies of extreme climate indices based on daily precipitation in the Carpathian Basin for the 20th century. Idöjárás 109, 1-20.

Bartholy, J., Pongrácz, R., and Hollósi, B., 2013: Analysis of projected drought hazards for Hungary. Adv. Geoscie. 35, 61-66. https://doi.org/10.5194/adgeo-35-61-2013

Beck, T., 2013: Principles of Ecological Landscape Design. Island Press, Washington, DC, USA. https://doi.org/10.5822/978-1-61091-199-3

Bede-Fazekas, Á., Trásy, K., and Csóka, Gy., 2015: Changing visual value of deciduous species in the climate change. In (Eds.: Wolf, J., Nečasová, J., Nečas, T.): Proceedings of the international conference "Horticulture in quality and culture of life". Mendel University in Brno, Faculty of Horticulture in Lednice, Lednice, Czech Republic.

Bede-Fazekas, Á. 2017: Fás szárú dísznövények potenciális telepíthetöségi területének elörejelzése természetközeli élőhelyekre készített modellek alapján. PhD dissertation. Szent István Egyetem, Gödöllő, Hungary. (In Hungarian)

Bede-Fazekas, Á., Czúcz, B., and Somodi, I., 2017: Vulnerability of natural landscapes to climate change - a case study of Hungary. Időjárás 121, 393-414.

Belda, M., Skalák, P., Farda, A., Halenka, T., Déqué, M., Csima, G., Bartholy, J., Torma, C., Boroneant, C., Caian, M., and Spiridonov, V., 2015: CECILIA regional climate simulations for future climate: Analysis of climate change signal. Adv. Meteorol. 2015(1), 354727.

Bivand, R., Keitt, T., and Rowlingson, B., 2014: rgdal: Bindings for the Geospatial Data Abstraction Library. R package version 0.8-16.

URL: https://cran.r-project.org/web/packages/rgdal/index.html

Bivand, R. and Lewin-Koh, N. 2015: maptools: Tools for Reading and Handling Spatial Objects. R package version 0.8-34. URL: https://cran.r-project.org/web/packages/maptools/index.html

Bivand. R.S., Pebesma, E., and Gomez-Rubio, V., 2013: Applied spatial data analysis with R. Springer, New York, NY, USA. https://doi.org/10.1007/978-1-4614-7618-4

Blanka, V., Mezösi, G., and Meyer, B., 2013: Projected changes in the drought hazard in Hungary due to climate change. Idöjárás 117, 219-237.

Dobor, L., Barcza, Z., Hlásny, T., Havasi, Á., Horváth, F., Ittzés, P., and Bartholy, J. 2015: Bridging the gap between climate models and impact studies: the FORESEE Database. Geoscie. Data J 2, 1-11. https://doi.org/10.1002/gdj3.22

Hijmans, R.J., 2015: raster: Geographic Data Analysis and Modeling. R package version 2.3-40. URL: https://cran.r-project.org/web/packages/raster/index.html

Horváth, L. 2008: Földrajzi analógia alkalmazása klímaszcenáriók elemzésében és értékelésében. PhD dissertation. Corvinus Egyetem of Budapest, Faculty of Horticultural Science, Budapest, Hungary. (In Hungarian)

Hunter, M., 2011: Using Ecological Theory to Guide Urban Planting Design: An adaptation strategy for climate change. Landscape J. 30, 173-193. https://doi.org/10.3368/lj.30.2.173

Krüssmann, G., 1977: Manual of cultivated broad-leaved trees and shrubs. American Horticultural Society, Alexandria, VA, USA and Timber Press, Portland, OR, USA.

Lakatos, M., Szentimrey, T., and Bihari, Z., (2011): Application of gridded daily data series for calculation of extreme temperature and precipitation indices in Hungary. Idojjárás 115, 99-109.

Maráczi, K.H. and Baracsi, É., 2012: Melegigényes díszcserjék télállósági vizsgálatai. In (Ed. Pannon Egyetem Georgikon Kar) LIV. Georgikon Napok. A mezőgazdaságtól a vidékgazda(g)ságig 54th Georgikon Scientific Conference. Pannon Egyetem Georgikon Kar, Keszthely, Hungary. (In Hungarian)

Mátyás, Cs., 1994: Modelling climate change effects with provenance test data. Tree Physiol. 14, $797-$ 804. https://doi.org/10.1093/treephys/14.7-8-9.797 
Mátyás, Cs. and Czimber, K., 2000: Zonális erdőtakaró mezoklíma szintü modellezése: lehetőségek a klímaváltozás hatásainak elörejelzésére. In: (Ed. Tar, K.) III. Erdő és Klíma Konferencia Debrecen, DE-TTK Meteorológia Tanszék, Debrecen, Hungary. (In Hungarian)

Nakićenović, N. and Swart, R,. (eds.) 2000: Emissions Scenarios. Cambridge University Press, Cambridge, UK.

Pálfai, I. 2002: Magyarország aszályossági zónái. Vízügyi Közlemények 84, 323-357. (In Hungarian)

Pálfai, I. 2004: Belvizek és aszályok Magyarországon. Hidrológiai tanulmányok. Vizzügyi Közlemények 86, 318-320.

Pebesma, E.J. and Bivand, R.S., 2005: Classes and methods for spatial data in R. R News 5(2).

Pongrácz, R., Bartholy, .J, and Kis, A., 2014: Estimation of future precipitation conditions for Hungary with special focus on dry periods. Időjárás 118, 305-321.

R Core Team, 2014: R: A language and environment for statistical computing. R Foundation for Statistical Computing, Vienna, Austria. URL: https://www.r-project.org/

Retkes, J. and Tóth, I., 2015: Lombos fák, cserjék. Nyugat-dunántúli Díszfaiskolások Egyesülete, Szombathely, Hungary. (In Hungarian)

Retkes, J. and Tóth, I., 2004: Lombos fák, cserjék. Mezőgazda Kiadó, Budapest, Hungary. (In Hungarian)

Roloff, A., Korn, S., and Gillner, S., 2009: The Climate-Species-Matrix to select tree species for urban habitats considering climate change. Urban Forest. Urban Green. 8, 295-308. https://doi.org/10.1016/j.ufug.2009.08.002

Sábitz, J., Szépszó, G., Zsebeházi, G., Szabó, P., Illy, T., Bartholy, J., Pieczka, I., and Pongrácz, R., 2015: A klímamodellekből levezethető indikátorok alkalmazási lehetőségei. NATéR EEA-C11-1 beszámoló.

URL: www.met.hu/downloads.php?fn=/RCMTeR/doc/reports/C11-1_indikatorok_tanulmany.pdf

Schmidt, G., 2006: Klíma- és időjárás-változás és a fás szárú dísznövények. In: C̄sete L, Nyéki J (eds.): Klímaváltozás és a magyarországi kertgazdaság. AGRO-21 Kutatási Programiroda, Budapest, Hungary. (In Hungarian)

Schmidt, G. and Sütöriné Diószegi, M., 2010: Testing urban climate with heat-tolerant woody plants in the Buda Arboretum. In: Proc. Int. Symp. Plants in Urban Areas and Landscape. Slovak University of Agriculture in Nitra, Nitra, Slovakia.

Schmidt, G., Tóth, I., and Sütöriné Diószegi, M., 2013: Dendrológia (tanulmányi segédlet). Budapesti Corvinus Egyetem, Kertészettudományi Kar, Dísznövénytermesztési és Dendrológiai Tanszék, Budapest, Hungary. (In Hungarian)

Sheffield, J. and Wood, E.F., 2008: Global trends and variability in soil moisture and drought characteristics, 1950-2000, from observation-driven simulations of the terrestrial hydrologic cycle. J. Climate 21, 432-458. https://doi.org/10.1175/2007JCLI1822.1

Soltész, M., Nyéki, J., and Lévai, P., 2011: Az aszály és szárazodás elleni küzdelem a kertészeti termelésben. "Klíma-21" Füzetek 64, 5-11.

Somodi, I., Molnár, Zs., Czúcz, B., Bede-Fazekas, Á., Bölöni, J., Pásztor, L., Laborczi, A., and Zimmermann, N.E., 2017: Implementation and application of Multiple Potential Natural Vegetation models - a case study of Hungary. J. Vegetat. Sci. 28, 1260-1269. https://doi.org/10.1111/jvs.12564

Steinhauser, F. 1970: Climatic atlas of Europe I. Maps of mean temperature and precipitation. WMO Unesco Cartographia Hungary, Budapest, Hungary.

Szabó, K. and Bede-Fazekas, Á., 2012: A forgalomban lévő fásszárú dísznövénytaxonok szárazságtürésének értékelése a klímaváltozás tükrében. Kertgazdaság 44(4), 62-73. (In Hungarian)

Szabó, K. and Gerzson, L., 2011: Evaluation of the Winter-hardy Yucca taxa among extreme conditions in landscape applications. Acta Universitatis Sapientiae Agriculture and Environment 3(Suppl.), 122-131.

Szentkirályi, F., Leskó, K. and, Kádár, F., 1998: Aszályos évek hatása a rovarpopulációk hosszú távú fluktuációs mintázatára. In (Eds. Tar, K., Szilágyi, K.) II. Erdő és Klíma Konferencia, Sopron, 1997. június 4-6. Kossuth Egyetemi Kiadó, Debrecen, Hungary. (In Hungarian) 
Torma, Cs. 2011: Átlagos és szélsőséges hőmérsékleti és csapadék viszonyok modellezése a Kárpátmedencére a XXI. századra a RegCM regionális klímamodell alkalmazásával. PhD dissertation. Eötvös Loránd University, Budapest, Hungary. (In Hingarian)

Torma, Cs., Bartholy, J., Pongrácz, R., Barcza, Z., Coppola, E., and Giorgi, F., 2008: Adaptation of the RegCM3 climate model for the Carpathian Basin. Időjárás 112, 233-247.

Torma, Cs., Coppola, E., Giorgi, F., Bartholy, J., and Pongrácz, R. 2011: Validation of a HighResolution Version of the Regional Climate Model RegCM3 over the Carpathian Basin. $J$. Hydrometeorol. 12, 84-100. https://doi.org/10.1175/2010JHM1234.1

Tóth, I., 2012: Lomblevelü díszfák, díszcserjék kézikönyve. Tarkavirág Kereskedelmi és Szolgáltató Kft, Budapest, Hungary. (In Hungarian)

Van Oldenborgh, G.J., Collins, M., Arblaster, J., Christensen, J.H., Marotzke, J., Power, S.B., Rummukainen, M., and Zhou, T., 2013: Annex I: Atlas of Global and Regional Climate Projections Supplementary Material RCP8.5. In (Eds. Stocker, T.F., Qin, D., Plattner, G.-K., Tignor, M., Allen, S.K., Boschung, J., Nauels, A., Xia, Y., Bex, V., Midgley, P.M.) Climate Change 2013: The Physical Science Basis Contribution of Working Group I to the Fifth Assessment Report of the Intergovernmental Panel on Climate Change.

URL: https://www.ipcc.ch/pdf/assessment-report/ar5/wg1/WG1AR5_AnnexI_FINAL.pdf

Vermes, L., Fésüs, I., Nemes, C., Pálfai, I., and Szalai, S. 2000: Status and progress of the national drought mitigation strategy in Hungary. In (Eds. Vermes, L., Szemessy, A.): Proceedings of the Central and Eastern European Workshop on Drought Mitigation. RePRINTStudio, Budapest, Hungary. 


\section{Supplementary Material}

S1. Aggregated species list of the category 'drought tolerant' of Szabó and Bede-Fazekas (2012) and the related categories '1-1', '1-2', '1-3', and '1-4' of climate-species matrix of Roloff et al. (2009). Species that are not mentioned by Roloff et al. (2009) are marked with asterisk.

1-1: very suitable based on the assessment in both categories (drought tolerance, hardiness)

1-2: very suitable according to their assessment in the category drought tolerance and as suitable in the category hardiness

1-3: very suitable according to their assessment in the category drought resistance and problematic in the category hardiness

1-4: very suitable according to their assessment in the category drought resistance and as not very suitable in the category hardiness

\begin{tabular}{|l|l|l|}
\hline Scientific name & Common name & $\begin{array}{l}\text { Classification in } \\
\text { climate-species matrix }\end{array}$ \\
\hline Abies cephalonica Loudon & Greek fir & $*$ \\
\hline Abies lasiocarpa (Hooker) Nuttall & Subalpine fir & $*$ \\
\hline Acer campestre L. & Field maple & $1-1$ \\
\hline Acer henryi Pax & Henry's maple & $*$ \\
\hline Acer tataricum L. & Tatarian maple & $1-1$ \\
\hline Albizia julibrissin (Durazz.) Baker & Persian silk tree & $*$ \\
\hline Amelanchier ovalis Medik. & Snowy mespilus & $1-1$ \\
\hline Berberis $\times$ frikartii C.K.Schneid. & Frikarts barberry & $*$ \\
\hline Berberis $\times$ media & Media barberry & $*$ \\
\hline Berberis $\times$ ottawensis C.K.Schneid. & Ottawensis barberry & $*$ \\
\hline Berberis julianae Schneid. & Wintergreen barberry & $*$ \\
\hline Berberis thunbergii DC. & Japanese barberry & $*$ \\
\hline Betula ermanii Cham. & Erman's birch & $*$ \\
\hline Betula pendula Roth & Silver birch & $2-1$ \\
\hline Buddleja alternifolia Maxim. & $\begin{array}{l}\text { alternate-leaved butterfly- } \\
\text { bush }\end{array}$ & $*$ \\
\hline Caragana arborescens Lam. & Siberian peashrub & $1-1$ \\
\hline Caryopteris $\times$ clandonensis & hibrid bluebeard & $*$ \\
\hline Caryopteris incana (Thunb. ex Houtt.) Miq. & bluebeard & $*$ \\
\hline Celtis australis L. & European hackberry & $1-3$ \\
\hline Celtis occidentalis L. & Hackberry & $1-2$ \\
\hline Cercis siliquastrum L. & Judas-tree & $1-4$ \\
\hline$\times$ Chitalpa tashkentensis Ellis and Wisura & Chitalpa & $*$ \\
\hline Cornus macrophylla Wallich in Roxburgh & Large-leafed dogwood & $*$ \\
\hline Cornus mas L. & Cornelian-cherry & $1-1$ \\
\hline Cornus sanguinea L & Common dogwood & $*$ \\
\hline Corylus avellana L. & Common hazel & $3-1$ \\
\hline & & \\
\hline
\end{tabular}




\begin{tabular}{|c|c|c|}
\hline Scientific name & Common name & $\begin{array}{l}\text { Classification in } \\
\text { climate-species matrix }\end{array}$ \\
\hline Corylus colurna L. & Turkish hazel & $2-2$ \\
\hline Cotinus coggygria Scop. & European smoketree & $*$ \\
\hline Cotoneaster acutifolius Turcz. & Peking cotoneaster & $*$ \\
\hline Cotoneaster horizontalis Decne. & Horizontal cotoneaster & $*$ \\
\hline Crataegus $\times$ lavallei Hénricq. Ex Lavallée & Hiibrid cockspur thorn & $1-1$ \\
\hline Crataegus $\times$ mordenensis Boom & Morden hawthorn & $*$ \\
\hline Crataegus coccinoides Ashe & Kansas hawthorn & $*$ \\
\hline Crataegus laevigata (Poir.) DC. & English hawthorn & $3-1$ \\
\hline Crataegus monogyna Jack. & Common hawrhorn & $2-1$ \\
\hline Crataegus persimilis Sarg. & broad-leaved cockspur thorn & $*$ \\
\hline Crataegus pinnatifida Bunge & Chinese hawthorn & $*$ \\
\hline Cupressus arizonica Greene & Arizona cypress & $1-2$ \\
\hline Cupressus sempervirens L. & Mediterranean cypress & $1-4$ \\
\hline Elaeagnus angustifolia L. & Russian-olive & $1-2$ \\
\hline Euonymus europaeus L. & Europaen spindletree & $3-1$ \\
\hline Fallopia baldschuanica (Regel) Holub & Russian-vine & $*$ \\
\hline Fraxinus ornus L. & Manna ash & $1-4$ \\
\hline Gleditsia triacanthos L. & Honey-locust & $1-2$ \\
\hline Gymnocladus dioicus (L.) K.Koch & Kentucky coffeetree & $2-2$ \\
\hline Hedera helix L. & common ivy & $*$ \\
\hline Hippophae rhamnoides L. & Sea buckthorn & $2-1$ \\
\hline $\begin{array}{l}\text { Juniperus } \times \text { pfitzeriana (Spath) P. A. } \\
\text { Schmidt) }\end{array}$ & Pfitzer Chinese juniper & $*$ \\
\hline Juniperus bermudiana L. & Bemuda juniper & $*$ \\
\hline Juniperus chinensis L. & Chinese juniper & $*$ \\
\hline Juniperus communis L. & Common juniper & $1-1$ \\
\hline Juniperus conferta Parl & shore juniper & $*$ \\
\hline Juniperus deppeana Steud & alligator juniper & $*$ \\
\hline Juniperus horizontalis Moenc & American savin & $*$ \\
\hline Juniperus pingii W. C. Cheng & ping-en & $*$ \\
\hline Juniperus sabina L. & sabina & $*$ \\
\hline Juniperus scopulorum Sarg. & Rocky mountain red-cedar & $1-1$ \\
\hline Juniperus virginiana $L$. & Eastern red-cedar & $1-1$ \\
\hline Koelreuteria paniculata Laxm. & Goldenrain-tree & $1-4$ \\
\hline Kolkwitzia amabilis Graebn. & Beautybush & $*$ \\
\hline Laburnum anagyroides Medik. & Common laburnum & $2-2$ \\
\hline Lavandula angustifolia Mill. & Lavender & $*$ \\
\hline Ligustrum vulgare L. & Common privet & $2-1$ \\
\hline
\end{tabular}




\begin{tabular}{|c|c|c|}
\hline Scientific name & Common name & $\begin{array}{l}\text { Classification in } \\
\text { climate-species matrix }\end{array}$ \\
\hline Lonicera maackii (Rupr.) Maxim. & Amur honeysuckle & $*$ \\
\hline Lonicera tatarica L. & Tartarian honeysuckle & $2-1$ \\
\hline Lonicera xylosteum L. & European fly honeysuckle & $*$ \\
\hline Perovskia atriplicifolia Benth. & Russian-sage & $*$ \\
\hline Physocarpus opulifolius (L.) Maxim. & Atlantic ninebark & $*$ \\
\hline Pinus mugo Turra & Mountain pine & $2-1$ \\
\hline Pinus nigra Arnold. & Black pine & $1-1$ \\
\hline Pinus sylvestris L. & Scots pine & $1-1$ \\
\hline Platycladus orientalis (L.) Franco & Chinese thuja & $*$ \\
\hline Prunus cerasifera Ehrh. & Cherry plum & $1-2$ \\
\hline Prunus dulcis (Mill.) D.A.Webb. & Almond & $1-4$ \\
\hline Prunus fruticosa Pall & European dwarf cherry & $1-2$ \\
\hline Prunus serotina Ehrh. & Black cherry & $*$ \\
\hline Prunus tenella Batsch & Russian almond & $*$ \\
\hline Punica granatum L. & pomegranate & $*$ \\
\hline Pyracantha coccinea M.J.Roem. & Firethorn & $1-2$ \\
\hline Pyrus $\times$ nivalis Jacq. & Snow pear & $*$ \\
\hline Pyrus calleryana Decne. & Bradford pear & $1-2$ \\
\hline Pyrus communis L. & Common pear & $2-2$ \\
\hline Pyrus elaeagrifolia Pall. & Oleaster-leafed pear & $2-2$ \\
\hline Rhus typhina L. & Staghorn sumac & $1-1$ \\
\hline Ribes aureum Pursh & Golden currant & $*$ \\
\hline Robinia hispida L. var. kelseyi (Hutch.) Isely & Bristly locust & $*$ \\
\hline Robinia pseudoacacia L. & Black locust & $1-1$ \\
\hline Rosa canina L. & Dog rose & $1-1$ \\
\hline Rosa spinosissima L. & Burnet rose & $*$ \\
\hline Salvia officinalis L. & Sage & $*$ \\
\hline Santolina chamaecyparissus L. & Lavender-cotton & $*$ \\
\hline Sorbus decipientiformis (Ehrh.) Pers. & Swedish whitebeam & $*$ \\
\hline Sorbus domestica L. & Service tree & $1-2$ \\
\hline Sorbus pseudolatifolia Boros & - & $*$ \\
\hline Sorbus torminalis (L.) Crantz & Wild service tree & $1-2$ \\
\hline Spartium junceum L. & Spanish-broom & $*$ \\
\hline Styphnolobium japonicum (L.) Schott & Pagoda-tree & $1-2$ \\
\hline Symphoricarpos $\times$ chenaultii Rehder & Chenault coralberry & $*$ \\
\hline Symphoricarpos $\times$ doorenbosii Krussm. & Garten-Schneebeere & $*$ \\
\hline Symphoricarpus orbiculatus Moench & Coralberry & $*$ \\
\hline Syringa vulgaris L. & Common lilac & $2-1$ \\
\hline
\end{tabular}




\begin{tabular}{|l|l|l|}
\hline Scientific name & Common name & $\begin{array}{l}\text { Classification in } \\
\text { climate-species matrix }\end{array}$ \\
\hline Tamarix gallica L. & French tamarisk & $*$ \\
\hline Tamarix tetrandra Pall. Ex M. Bieb. & Small-flower tamarisk & $1-2$ \\
\hline Tetradium daniellii (Benn.) Hartl. & Euodia & $3-4$ \\
\hline Ulmus minor Mill. & European field elm & $*$ \\
\hline Ulmus pumila L. & Siberian elm & $1-1$ \\
\hline Viburnum $\times$ rhytidophylloides Valck. Sur. & Hibrid viburnum & $*$ \\
\hline Viburnum lantana L. & Mealytree & $1-1$ \\
\hline Vitex agnus-castus L. & Chasteberry & $*$ \\
\hline Yucca filamentosa L. & Adam's-needle & $*$ \\
\hline Zelkova serrata (Thunb. Ex Murray) Makino & Japanese zelkova & $2-2$ \\
\hline
\end{tabular}

